\title{
Sources and fluxes of organic nitrogen in precipitation over the southern East Sea/Sea of Japan
}

\author{
G. Yan and G. Kim \\ School of Earth \& Environmental Sciences/RIO, Seoul National University, Seoul 151-747, South Korea \\ Correspondence to: G. Kim (gkim@snu.ac.kr)
}

Received: 22 August 2014 - Published in Atmos. Chem. Phys. Discuss.: 18 December 2014

Revised: 17 February 2015 - Accepted: 18 February 2015 - Published: 10 March 2015

\begin{abstract}
We measured total dissolved reactive nitrogen in precipitation samples collected at Uljin, a Korean coastal site upwind of the southern East Sea/Sea of Japan (EJS), selected as a representative study site of atmospheric deposition over the northwestern Pacific margin. $\mathrm{NO}_{3}^{-}$was found to be the most abundant nitrogen species, followed by $\mathrm{NH}_{4}^{+}$and dissolved organic nitrogen (DON). Air-mass back-trajectory (AMBT) analysis revealed that a significant fraction of the inorganic nitrogen $\left(\mathrm{NO}_{3}^{-}\right.$and $\left.\mathrm{NH}_{4}^{+}\right)$originated from mainland Asia, whereas the DON was primarily derived from Korea. Using varimax-rotated factor analysis in combination with major ions as tracers, agricultural activities in Korea were identified as the primary sources of DON in these samples. In addition, a positive correlation was found at Uljin between the size of organic fraction in total reactive nitrogen and nitrogen to carbon atomic ratio in organic matter. This correlation has also been observed at other locations worldwide, implying the utilization potential of atmospheric organic nitrogen might increase with its proportion in total nitrogen. Combining wet deposition measurements in this study with literature values for dry deposition observed at a remote island in the EJS, the total atmospheric depositional flux of reactive nitrogen was estimated to be $115 \mathrm{mmol} \mathrm{N} \mathrm{m}^{-2} \mathrm{yr}^{-1}$ over the southern EJS. Our study sheds new light on the potentially significant contribution to primary productivity of the northwestern Pacific Ocean by atmospheric deposition of nitrogen, especially the organic fraction.
\end{abstract}

\section{Introduction}

The availability of reactive nitrogen (or fixed nitrogen), including all nitrogen species except $\mathrm{N}_{2}$, is often a determinant controlling the primary production in terrestrial and marine ecosystems (Vitousek and Howarth, 1991). However, since the mid-1800s the global nitrogen cycle has been significantly perturbed by excessive production of reactive nitrogen through human activities (at a similar rate to natural biological fixation) (Dentener et al., 2006; Galloway et al., 2008; Fowler et al., 2013), such as the Haber-Bosch process, fossil-fuel combustion, and legume cultivation (Gruber and Galloway, 2008). A fraction of the reactive nitrogen is transported from continents to oceans via rivers, groundwater, and the atmosphere, exerting a significant influence on marine ecology and biogeochemistry (e.g., acidification, eutrophication, and oxygen depletion) (Seitzinger et al., 2005; Paytan et al., 2006; Doney et al., 2007; Krishnamurthy et al., 2010). In particular, the supply of external or new nitrogen to marine systems through atmospheric deposition can be substantial in some marginal and coastal seas (Beddig et al., 1997; Castro and Driscoll, 2002; de Leeuw et al., 2003; Uno et al., 2007; Zhang et al., 2010), as well as the open ocean (Galloway et al., 2004; Duce et al., 2008).

The East Sea/Sea of Japan (EJS) is a semi-closed marginal sea (covering an area of $1.01 \times 10^{6} \mathrm{~km}^{2}$ ) surrounded by Russia, Korea, and Japan, which has been suggested to be an ideal site to investigate the impacts of atmospheric nutrient deposition on the northwestern Pacific Ocean (Kim and Kim, 2013). It is a highly productive region where nitrogen is severely limited (Talley et al., 2004; Jenkins, 2008; Kim and Kim, 2013). Therefore, the supply of reactive nitrogen is particularly important in determining the primary productivity of this marine ecosystem. In addition to the upwelling 
of deep waters and $\mathrm{N}_{2}$ fixation by diazotrophs within the ocean, land-derived reactive nitrogen (which is largely anthropogenic) can also contribute to the nitrogen required for primary production in the EJS. Since no major rivers flow into the EJS from the surrounding coasts, the fluvial inputs of nitrogen can be ignored (Kang et al., 2009; Yoo and Park, 2009). Nevertheless, terrigenous nitrogen transported via the atmosphere may reach the open ocean, contributing to the nitrogen inventory across the EJS. In fact, the mid- and longrange atmospheric transport of dust and pollutants from land to the northwestern Pacific Ocean (including the EJS) has been shown to be remarkable (Jo et al., 2007; Kang et al., 2009, 2011; T. W. Kim et al., 2011; Zhang et al., 2011), particularly since this region is located downwind of East Asia, a densely populated area characterized by intensive emissions of aerosols and gases by anthropogenic and natural processes (Cooke et al., 1999; Richter et al., 2005; Kim, 2008). Recently, T. W. Kim et al. (2011) suggested the significant atmospheric nitrogen deposition has switched extensive parts of the northwestern Pacific Ocean (including the EJS) from being nitrogen limited to phosphorous limited during the last 3 decades. A follow-up study by Kim et al. (2013), however, attributed this increasing trend in relative abundance of nitrogen over phosphorous to nutrient transport by ocean currents. Nevertheless, Kim and Kim (2013) argued that this oceanic region would remain nitrogen limited for the next 100 years, based on observational data and model predictions. The debate aroused here signifies the importance of an unambiguous budget of nitrogen in the EJS, especially the fraction transported by the atmosphere, which is poorly constrained due to a lack of data (Zhang et al., 2011).

The atmospheric deposition of nitrogen over the southern EJS was previously evaluated by Kang et al. (2010) using dry deposition observations combined with estimates for wet deposition. However, their approximation on nitrogen deposition was an underestimate, since it did not take into account organic nitrogen, which is a globally significant constituent of total reactive nitrogen in the atmosphere (ca. 30\% on average) (Jickells, 2006; Cape et al., 2011; Cornell, 2011). Indeed, the growing weight of evidence from global observational studies suggests that a considerable fraction of deposited nitrogen is in organic form (Cornell, 2011, and references therein), which is able to stimulate the productivity of bacteria and phytoplankton in the receiving marine ecosystems (Seitzinger and Sanders, 1999; Bronk et al., 2007). In particular, atmospheric organic nitrogen deposition was shown to be especially high over Asia (Cornell, 2011; Ito et al., 2014), implying it is imperative to incorporate this fraction into the budget of atmospheric nitrogen input to the EJS. Nevertheless, although quantitatively significant, the sources, chemical compositions, and bioavailability of atmospheric organic nitrogen are largely unknown (Mace et al., 2003a; Duce et al., 2008; Jickells et al., 2013), hindering our understanding of its biogeochemical role in the receiving ecosystems.
In order to provide better constraints on atmospheric nitrogen deposition to the EJS, we analyzed reactive nitrogen species (inorganic and organic) and major ions in precipitation samples collected at a coastal site upwind of this marginal sea. The emphasis of the present work was placed on organic nitrogen, which has been ignored in previous study and is generally poorly characterized in comparison with its inorganic counterpart. With the aid of air-mass backtrajectory (AMBT) and factor analysis, the geographical and emission sources of organic nitrogen were explored. Moreover, using the calculated total nitrogen depositional flux, the fraction of new primary production of the EJS which is potentially supported by atmospheric nitrogen deposition was estimated.

\section{Materials and methods}

\subsection{Study site and sample collection}

The sampling campaign was conducted at Uljin $\left(37^{\circ} \mathrm{N}\right.$, $129.4^{\circ} \mathrm{E}$ ), which is located on the eastern coastline of Korea (Fig. 1). It is a rural area with a small population of around 52000 inhabiting an area of $989.06 \mathrm{~km}^{2}$. Precipitation samples $(N=33)$ were collected on an event basis on the rooftop of a four-story research facility (ca. $16 \mathrm{~m}$ above the ground) at the Korean Institute of Ocean Science and Technology (East Sea branch) from February 2011 to January 2012. A home-made sampler was employed, which is composed of a polypropylene funnel (diam. $250 \mathrm{~mm}$ ) connected by Tygon FEP-lined tubing to a high-density polyethylene (HDPE) bottle placed in a covered bucket. Prior to use, the apparatus was thoroughly cleaned using dilute hydrochloric acid and rinsed with deionized (Milli-Q) water $(18.2 \mathrm{M} \Omega \mathrm{cm})$. The sampler was manually deployed at the onset of the precipitation events and retrieved after cessation. The impacts of dry deposition were minimized by restricting the exposure time to dry conditions (i.e., $<1 \mathrm{~h}$ for daytime events or $\leq 5 \mathrm{~h}$ for overnight events). After collection, the samples were transferred to a laminar flow clean room and filtered through precombusted $\left(5 \mathrm{~h}\right.$ at $\left.500^{\circ} \mathrm{C}\right)$ Whatman $0.7 \mu \mathrm{m} \mathrm{GF} / \mathrm{F}$ glass fiber filters. Subsamples for dissolved organic carbon (DOC) analysis were placed in $20 \mathrm{~mL}$ pre-muffled glass ampoules $(5 \mathrm{~h}$ at $500^{\circ} \mathrm{C}$ ) and chemically preserved with $6 \mathrm{M}$ pure hydrochloric acid, followed by fire sealing. Aliquots for dissolved nitrogen species and major ions were stored in pre-cleaned HDPE bottles and kept frozen at $-20^{\circ} \mathrm{C}$ until analysis.

\subsection{Analytical methods}

Total dissolved nitrogen (TDN) and DOC concentrations were measured simultaneously by high-temperature catalytic oxidation (HTCO) using a Shimadzu TOC/TN analyzer (Model TOC- $\mathrm{V}_{\mathrm{CPH} / \mathrm{CPN}}$ ) equipped with an ASI-V autosampler. The acidified samples ( $\mathrm{pH}<2$ using $\mathrm{HCl}$ ) were sparged with carbon dioxide free carrier gas (UHP oxygen) at a 
Table 1. Statistical summary of concentrations of dissolved chemical species in precipitation analyzed in this study (unit: $\mu$ mol $\mathrm{L}^{-1}$ ).

\begin{tabular}{lcccccccccc}
\hline & $\mathrm{NO}_{3}^{-}$ & $\mathrm{NH}_{4}^{+}$ & $\mathrm{ON}$ & $\mathrm{Na}^{+}$ & $\mathrm{K}^{+}$ & $\mathrm{Mg}^{2+}$ & $\mathrm{Ca}^{2+}$ & $\mathrm{Cl}^{-}$ & $\mathrm{SO}_{4}^{2-}$ & $\mathrm{OC}$ \\
\hline Min. & 2 & 1 & $\mathrm{BD}^{\mathrm{a}}$ & 8 & 2 & 2 & 7 & 13 & 4 & 9 \\
1st quartile & 12 & 5 & 7 & 55 & 8 & 7 & 18 & 82 & 23 & 61 \\
Median & 31 & 24 & 13 & 138 & 15 & 28 & 46 & 206 & 58 & 156 \\
3rd quartile & 74 & 34 & 40 & 900 & 25 & 108 & 68 & 1580 & 117 & 296 \\
Max. & 428 & 139 & 145 & 2930 & 69 & 337 & 259 & 3780 & 215 & 849 \\
Mean & 58 & 39 & 30 & 635 & 21 & 76 & 57 & 894 & 83 & 219 \\
VWA $^{\mathrm{b}}$ & 20 & 14 & 13 & 430 & 13 & 47 & 25 & 578 & 43 & 97 \\
\hline
\end{tabular}

a Below detection limit.

$\mathrm{b}$ Volume-weighted average.

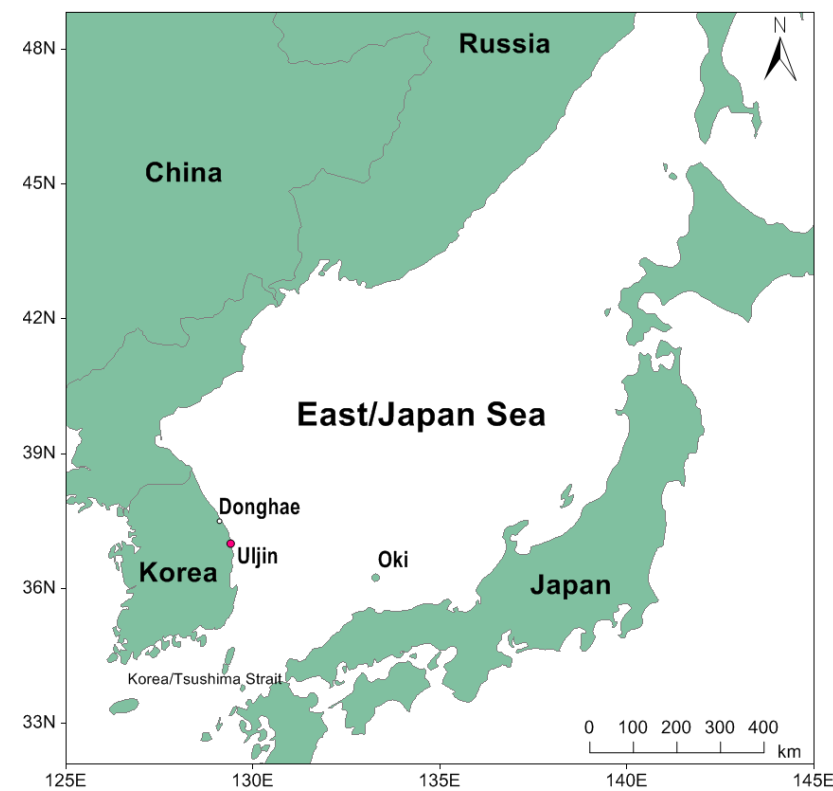

Figure 1. Map showing the location of Uljin (sampling site; $37^{\circ} \mathrm{N}$, $\left.129.4^{\circ} \mathrm{E}\right)$, Donghae $\left(37.5^{\circ} \mathrm{N}, 129.1^{\circ} \mathrm{E}\right)$, and Oki Island $\left(36.3^{\circ} \mathrm{N}\right.$, $\left.133.2^{\circ} \mathrm{E}\right)$.

flow rate of $150 \mathrm{ml} \mathrm{min}^{-1}$ for $2 \mathrm{~min}$ to remove inorganic carbon. Then the samples were injected into a combustion column packed with Pt coated alumina beads heated to $720^{\circ} \mathrm{C}$. The carbon dioxide and nitrogen monoxide evolving from combustion were detected by a non-dispersive infrared detector and a chemiluminescence detector, respectively. Major ions including inorganic nitrogen species were determined by high-performance liquid chromatography using a Waters 2695 high-performance liquid chromatographic (HPLC) system equipped with a Waters 432 conductivity detector. Cation analysis (i.e., $\mathrm{Na}^{+}, \mathrm{K}^{+}, \mathrm{Ca}^{2+}, \mathrm{Mg}^{2+}$, and $\mathrm{NH}_{4}^{+}$) was carried out using a mobile phase consisting of $3.0 \mathrm{mmol} \mathrm{L}^{-1} \mathrm{HNO}_{3}$ and $0.1 \mathrm{mmol} \mathrm{L}^{-1}$ Ethylenediaminetetraacetic acid (EDTA), and a Waters IC-Pak C M/D column $(150 \times 3.9 \mathrm{~mm}, 5 \mu \mathrm{m})$. Anions (i.e., $\mathrm{Cl}^{-}, \mathrm{NO}_{3}^{-}, \mathrm{NO}_{2}^{-}$, and $\mathrm{SO}_{4}^{2-}$ ) were analyzed using a borate/gluconate eluent con- taining $12 \%$ acetonitrile and a Waters IC-Pak A HR column $(75 \times 4.6 \mathrm{~mm}, 6 \mu \mathrm{m})$. The column was maintained at $30^{\circ} \mathrm{C}$ and the detector at $35^{\circ} \mathrm{C}$. Dissolved organic nitrogen (DON) was quantified as the difference between TDN and dissolved inorganic nitrogen (DIN), which is the sum of $\mathrm{NO}_{3}^{-}$and $\mathrm{NH}_{4}^{+}$ $\left(\mathrm{NO}_{2}^{-}\right.$in our samples was always below the detection limit and is therefore not included). This approach could yield large uncertainties for DON, especially when DIN dominates the nitrogen pool, as has been suggested by previous studies (Cornell et al., 2003; Lesworth et al., 2010). The average relative standard deviations associated with replicate measurements of standards were 4,2 , and $3 \%$ for TDN, $\mathrm{NO}_{3}^{-}$, and $\mathrm{NH}_{4}^{+}$, respectively. Based on error propagation using uncertainties of each analyte, the precision of DON was estimated to be less than $18 \%$ when DON \% is greater than $20 \%, 18$ $60 \%$ when DON \% varies from 5 to $20 \%$, and greater than $100 \%$ when DON \% is less than $5 \%$ (e.g., 18 March 2011, 30 May 2011, and 16 August 2011). The limits of detection calculated as 3 times the standard deviation of blanks are

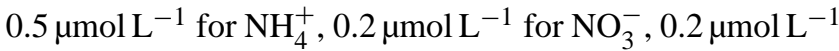
for $\mathrm{NO}_{2}^{-}, 1.1 \mu \mathrm{mol} \mathrm{L}-1$ for TDN, and $5.0 \mu \mathrm{mol} \mathrm{L}^{-1}$ for DOC. The detection limit for DON was estimated to be $1 \mu \mathrm{mol} \mathrm{L}-1$ (Cornell et al., 1998; Zhang et al., 2001; Walker et al., 2012), by using detection limits of relevant nitrogen species following error propagation rules for standard deviations. Certified reference materials (from University of Miami for DOC and TDN, and from National Research Council of Canada for DIN) were employed during the sample analysis to confirm the data quality.

\section{Results and discussion}

\subsection{Distributions of dissolved reactive nitrogen in precipitation}

\subsubsection{Concentrations and speciation}

The concentrations of dissolved reactive nitrogen showed considerable variations during the sampling year, ranging from 2 to $428 \mu \mathrm{mol} \mathrm{L}^{-1}$ for $\mathrm{NO}_{3}^{-}$, from 1 to $139 \mu \mathrm{mol} \mathrm{L}^{-1}$ 


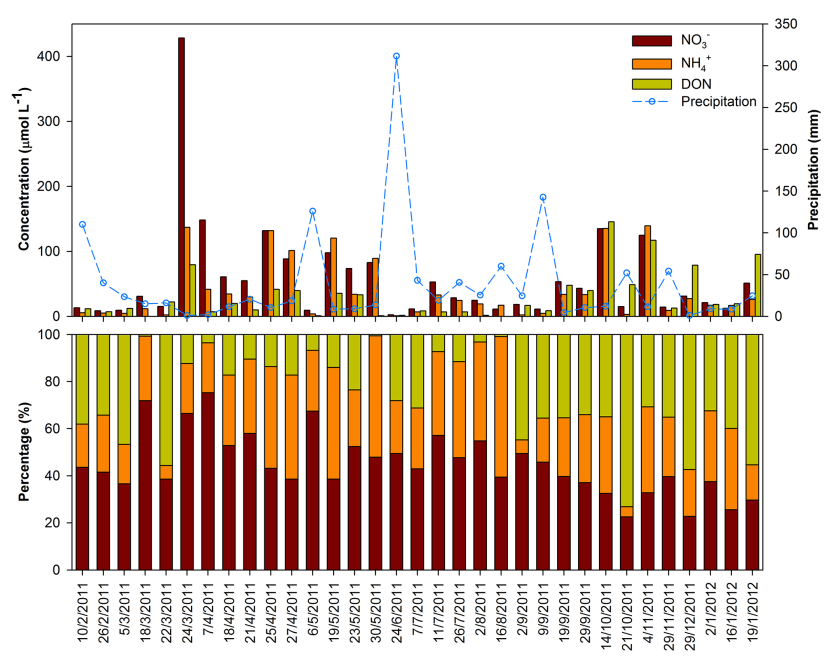

Figure 2. Concentrations (top) and percentages (bottom) of each reactive nitrogen species in precipitation samples collected at Uljin from 2011 to 2012 .

for $\mathrm{NH}_{4}^{+}$, and from below the detection limit to $145 \mu \mathrm{mol} \mathrm{L}-1$ for DON (Table 1 and Fig. 2). Rather similar temporal trends were found for all three nitrogen species, with high abundances observed in spring and fall (Fig. 2). Aside from the source strength, the distribution pattern displayed here is likely to be influenced by several factors specific to this location. The precipitation amount might be one of the most important factors, because the variation patterns of these nitrogen species are in general accordance with the precipitation regime of Korea (particularly high in summer), in a manner that the concentrations decrease as the precipitation depth increases. In addition, the wind systems (or air-mass origins) of Korea may also contribute significantly to the observed temporal trend (see Sect. 3.1.2.). The northwesterlies prevail most of the year, transporting large amounts of terrestrially derived nitrogen from inland Korea and the Asian continent (especially China) to Uljin and the EJS. In contrast, the prevailing wind over the summer blows from the Pacific Ocean, carrying precipitation associated with relatively pristine air masses.

Overall, $\mathrm{NO}_{3}^{-}$is the most abundant nitrogen species with an annual average concentration (AVG) of $58 \mu \mathrm{mol} \mathrm{L}^{-1}$ and a volume-weighted average (VWA) (Topol et al., 1985) of $20 \mu \mathrm{mol} \mathrm{L}{ }^{-1}$, followed by $\mathrm{NH}_{4}^{+}\left(\mathrm{AVG}=39 \mu \mathrm{mol} \mathrm{L}^{-1}\right.$; $\left.\mathrm{VWA}=14 \mu \mathrm{mol} \mathrm{L}^{-1}\right)$ and DON $\left(\mathrm{AVG}=30 \mu \mathrm{mol} \mathrm{L}^{-1}\right.$; $\mathrm{VWA}=13 \mu \mathrm{mol} \mathrm{L}^{-1}$ ) (Table 1 ). The reactive nitrogen concentrations in precipitation observed in this study are generally at the upper end of the range of literature values reported for coastal sites globally over the past decade (Keene et al., 2002; Luo et al., 2002; Mace et al., 2003b; Kieber et al., 2005; Calderon et al., 2007; Violaki et al., 2010; Cape et al., 2011; Zamora et al., 2011). However, much higher concentrations have been found in rainwater over coastal areas of China, which were attributed to significant pollution associated with the rapid economic development (Chen et al., 2011; Zhang et al., 2012). The relatively high levels of reactive nitrogen in the atmosphere at Uljin probably can be linked to the anthropogenic emissions of nitrogen in East Asia including Korea and subsequent atmospheric transport.

In contrast to observations from regions characterized by intensive agricultural practices (e.g., China and midwestern USA) (Fahey et al., 1999; Zhang et al., 2008), $\mathrm{NO}_{3}^{-}$showed higher abundances with respect to $\mathrm{NH}_{4}^{+}$, implying that combustion processes contributed more significantly than agricultural activities to reactive inorganic nitrogen in our samples (Galloway et al., 2004; Spokes and Jickells, 2005; Lee et al., 2012). A few exceptions were observed in April, May, October, and November (Fig. 2), when concentrations of $\mathrm{NH}_{4}^{+}$were similar to or higher than those of $\mathrm{NO}_{3}^{-}$. These exceptions can be attributed to enhanced agricultural activities (i.e., application of $\mathrm{N}$ fertilizer and livestock manure to the farmland) during these time periods in Korea (Lee at al., 2012). Although being a minor component, DON made up a considerable fraction ( $28 \%$ on average) of the TDN in our samples, approximating to that contributed by $\mathrm{NH}_{4}^{+}(30 \%$ on average). In comparison with $\mathrm{NO}_{3}^{-}$and $\mathrm{NH}_{4}^{+}$, the relative proportion of DON showed remarkable variations from sample to sample, which were found to be relatively lower from April to August (Fig. 2). The seasonality and air-mass origins might contribute to the pattern observed here to some extent. However, the major factors that control the proportion of organic nitrogen in atmospheric reactive nitrogen pool remain rather ambiguous (Cornell, 2011) (see Sect. 3.3.1 for further discussion).

\subsubsection{Potential source regions based on air-mass origins}

Atmospheric deposition plays an important role in global biogeochemical cycles, as it allows chemical substances to be transported to locations remote from their source regions over relatively short timescales. Therefore, the reactive nitrogen found in our samples was presumably subject to influences of air masses originating from distant areas. In order to explore the potential source regions and to assess the contributions by long-range atmospheric transport, the provenances of the air masses corresponding to each of the precipitation events were determined based on AMBT analysis, using the Global Data Assimilation System (GDAS) data set and the Hybrid Single-Particle Lagrangian Integrated Trajectory (HYSPLIT) model (version 4) developed at the Air Resources Laboratory of the National Oceanic and Atmospheric Administration (NOAA) (Draxler and Hess, 1998). Apart from the nearby continental regions (i.e., the Korean peninsula), reactive nitrogen could be transported over long distance to Uljin from mainland Asia as well as the surrounding oceans, as observed for other airborne species in Korea (Kim et al., 2005; Kim, 2008). Accordingly, based on calculated AMBTs, air-mass origins were sorted into three 
groups: Korean Peninsula (type I), Asian continent (type II), and Pacific Ocean (type III) (Fig. 3). A similar classification regime can be found in our previous study (Yan and Kim, 2012), in which detailed descriptions for each group were presented. It is noteworthy that the reactive nitrogen in each group does not exclusively come from the corresponding source region identified. For example, the precipitation events associated with long-range transported air masses inevitably receive some contributions from local sources.

The distribution patterns of VWA concentrations for the three groups were consistent for $\mathrm{NO}_{3}^{-}$and $\mathrm{NH}_{4}^{+}$, with the highest concentrations observed in type II and the lowest in type III (Fig. 4). As these two nitrogen species are known to be predominantly anthropogenic, this pattern is consistent with the air-mass origins proposed for these groups. Type II air masses also account for the largest fraction (47\%) of sampled precipitation events, suggesting a significant contribution to inorganic nitrogen at Uljin from the highly industrialized and urbanized areas of East Asia, especially eastern and northeastern China (Richter et al., 2005; Jeong and Park, 2008; Lee et al., 2014). The lowest VWA DON concentration was also observed for air masses derived from surrounding marine areas (type III), implying that marine biogenic emission is an insignificant source for DON at Uljin. In contrast to the pattern seen for inorganic nitrogen, the highest abundances of DON were associated with type I air masses. It is thereby inferred that the emission sources within Korea play a dominant role in supplying organic nitrogen to the atmosphere at our location. Despite the fact that the largest concentrations of atmospheric organic nitrogen worldwide have been observed in China (Cornell, 2011), type II air masses at Uljin were characterized by relatively lower DON abundances than type I. This could be partially due to the inclusion of clean marine air masses and/or the loss of the labile portion of organic nitrogen during the long-range transport. In addition, the highest proportion of DON (32\%) was also observed in type I air masses, confirming the importance of organic nitrogen from emissions in Korea.

\subsection{Source identification for DON}

While the major sources for inorganic reactive nitrogen in the atmosphere are known to be anthropogenic (Galloway et al., 2004; Fowler et al., 2013), the primary origins of the organic fraction remain poorly characterized (Cape et al., 2011; Cornell, 2011). Previous studies have suggested that atmospheric organic nitrogen may stem from a variety of natural and anthropogenic processes, including resuspension of soil dust, marine emissions, biomass burning, agricultural activities, industrial production, and fossil-fuel combustion (Jickells et al., 2013 and references therein). In this study, attempts were made to identify the major sources of DON in our precipitation samples, on the basis of factor analysis in combination with major ions as tracers. The results obtained from varimax-rotated factor analysis suggest that most variations
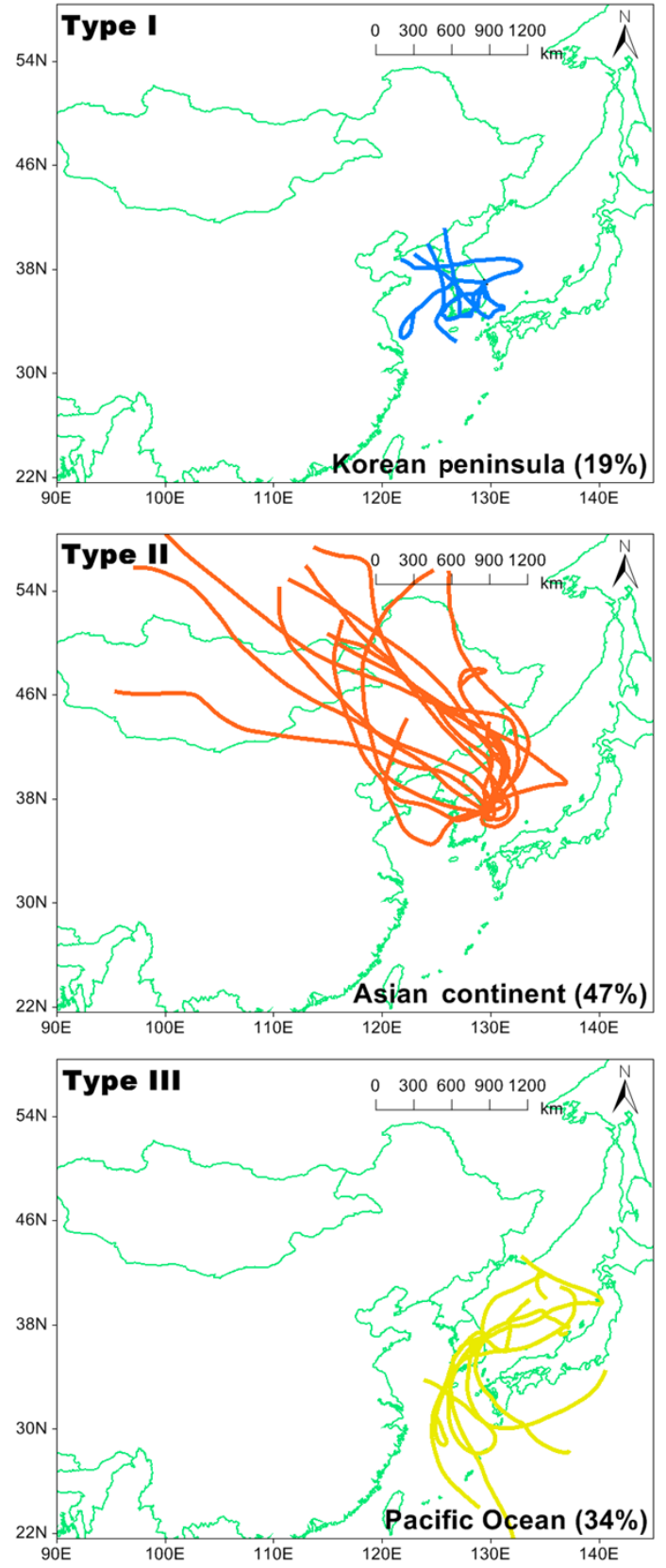

Figure 3. Three-day air-mass backward trajectories at $500 \mathrm{~m}$ (above ground level) for precipitation events at Uljin during the sampling period, obtained using the HYSPLIT model. The air-mass provenances are sorted into three groups: Korean Peninsula (type I), Asian continent (type II), and Pacific Ocean (type III). The percentage values in parentheses indicate the occurring frequencies of each type.

$(91 \%)$ in the nine variables included can be accounted for by three extracted factors (eigenvalue >1) (Table 2).

The first factor is characterized by high loadings of $\mathrm{Na}^{+}$, $\mathrm{K}^{+}, \mathrm{Mg}^{2+}, \mathrm{Cl}^{-}$, and $\mathrm{SO}_{4}^{2-}$. The enrichment factors (EFs) for these ions (except $\mathrm{Na}^{+}$) with respect to average seawa- 


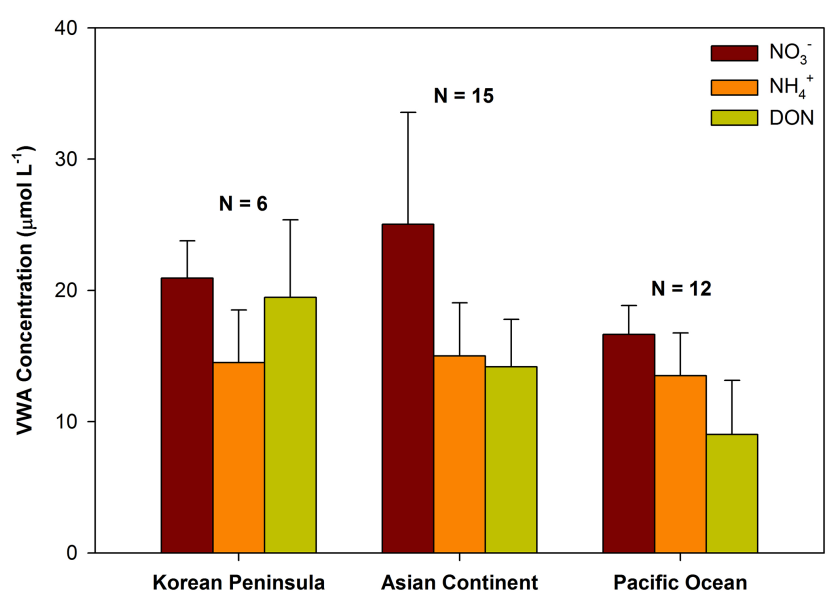

Figure 4. Volume-weighted average concentrations of reactive nitrogen species for precipitation events associated with the three types of air masses at Uljin. Error bars represent standard deviations.

Table 2. Varimax-rotated principal factor matrix* Factor loadings exceeding 0.7 are shown in bold.

\begin{tabular}{lrrr}
\hline & Factor 1 & Factor 2 & Factor 3 \\
\hline $\mathrm{NO}_{3}^{-}$ & -0.12 & $\mathbf{0 . 9 4}$ & 0.25 \\
$\mathrm{NH}_{4}^{+}$ & -0.12 & 0.59 & 0.46 \\
$\mathrm{ON}$ & 0.20 & 0.27 & $\mathbf{0 . 9 3}$ \\
$\mathrm{Na}^{+}$ & $\mathbf{0 . 9 8}$ & -0.05 & 0.10 \\
$\mathrm{~K}^{+}$ & $\mathbf{0 . 9 7}$ & 0.12 & 0.10 \\
$\mathrm{Mg}^{2+}$ & $\mathbf{0 . 9 9}$ & 0.02 & 0.02 \\
$\mathrm{Ca}^{2+}$ & 0.22 & $\mathbf{0 . 9 5}$ & 0.09 \\
$\mathrm{Cl}^{-}$ & $\mathbf{0 . 9 9}$ & -0.03 & 0.07 \\
$\mathrm{SO}_{4}^{2-}$ & $\mathbf{0 . 7 5}$ & 0.45 & 0.26 \\
Eigenvalue & 4.53 & 2.44 & 1.21 \\
\% Variance & 50.35 & 27.09 & 13.47 \\
\hline * The software package used for principal factor analysis is \\
SPSS 16.0.
\end{tabular}

ter composition were calculated using sodium as a reference element (Keene et al., 1986). The EFs fall in between 1 and 10 (Table 3), suggesting these chemical species are primarily derived from marine emissions (Poissant et al., 1994). This interpretation is confirmed by the significant positive correlations between the abundances of these ions and $\mathrm{Na}^{+}$ $\left(R^{2}=0.86\right.$ for $\mathrm{K}^{+}, 0.93$ for $\mathrm{Mg}^{2+}, 0.98$ for $\mathrm{Cl}^{-}$, and 0.51 for $\mathrm{SO}_{4}^{2-}$ ). Therefore, this factor probably can be attributed to the contributions from marine sources. The largest fraction of variance $(50 \%)$ (Table 2$)$ in the nine variables explained by this factor is consistent with the marine feature of Uljin. The second factor has high loadings of $\mathrm{NO}_{3}^{-}$and $\mathrm{Ca}^{2+}$, which are generally considered to be of different origins. In addition, moderate loadings are shown for $\mathrm{NH}_{4}^{+}$and $\mathrm{SO}_{4}^{2-}$ on this factor. In the atmosphere, $\mathrm{NO}_{3}^{-}$is mainly derived from $\mathrm{NO}_{2}$ emitted by fossil-fuel combustion (Dentener et al., 2006), whereas $\mathrm{Ca}^{2+}$ comes from both crustal and marine sources (Gabriel et al., 2002). The relatively highEF value (19.17) indicates that crustal contribution is more important for $\mathrm{Ca}^{2+}$ in our samples. This factor is therefore likely to represent a mixed source involving inputs from combustion processes as well as soil resuspension. The association of these ions (i.e., $\mathrm{Ca}^{2+}, \mathrm{NH}_{4}^{+}, \mathrm{NO}_{3}^{-}$, and $\mathrm{SO}_{4}^{2-}$ ) has frequently been observed in factor analysis conducted in previous studies (Hu et al., 2003; Wai et al., 2008; Song and Gao, 2009), and is attributed to the neutralization of acidic anions by alkaline cations in precipitation (Wai et al., 2008). Since the loadings of DON on these two factors are rather low, the contributions from marine emissions, soil dust, and combustion-related processes to DON are expected to be less significant.

The third factor is associated with a moderate loading of $\mathrm{NH}_{4}^{+}$and a high loading of DON. $\mathrm{NH}_{4}^{+}$in precipitation is derived from its gaseous precursor $\mathrm{NH}_{3}$, which is primarily released during agricultural activities such as animal husbandry and the application of synthetic fertilizer (Galloway et al., 2004). These activities are also known to be the origins of several important atmospheric organic nitrogen species (e.g., urea) (Cornell et al., 1998). According to statistical data from International Fertilizer Industry Association (2013), a considerable fraction of the nitrogen fertilizer consumed in Korea each year is in the form of urea. In addition, Lee et al. (2012) found $\mathrm{NH}_{4}^{+}$and $\mathrm{DON}$ in precipitation collected in a southern Korean city were mainly derived from fertilizer use and livestock excretion in surrounding rural areas using nitrogen isotopic analysis. This suggests that agricultural practices conducted within Korea could be a crucial source of $\mathrm{NH}_{3}$ and organic nitrogen in the atmosphere, which is in line with the conclusions drawn from the AMBT analysis that the Korean Peninsula contributes significantly to $\mathrm{NH}_{4}^{+}$ and DON in our samples (Fig. 4). Taken together, it is concluded that the primary fraction of DON in our samples originated from agricultural activities in Korea, albeit contributions from other anthropogenic and biogenic sources cannot be ruled out.

\subsection{Biogeochemical impacts of atmospheric nitrogen deposition on the EJS}

\subsubsection{Seasonal variations in nitrogen fluxes and DON proportions}

The wet depositional fluxes (defined as the product of concentration and precipitation depth) of the three reactive nitrogen species showed remarkable seasonal variations, with relatively high values observed in spring and fall for $\mathrm{NO}_{3}^{-}$ and $\mathrm{NH}_{4}^{+}$, and in fall and winter for DON, (Fig. 5). While being a minor component in spring and summer, DON made up the largest fraction of the TDN fluxes in fall and winter. Precipitation amount is discounted as the cause of this temporal trend as it shows no correlation with the variations in 
Table 3. Enrichment factors of major ions in precipitation at Uljin relative to seawater.

\begin{tabular}{lccccc}
\hline & $\mathrm{K}^{+} / \mathrm{Na}^{+}$ & $\mathrm{Mg}^{2+} / \mathrm{Na}^{+}$ & $\mathrm{Ca}^{2+} / \mathrm{Na}^{+}$ & $\mathrm{Cl}^{-} / \mathrm{Na}^{+}$ & $\mathrm{SO}_{4}^{2-} / \mathrm{Na}^{+}$ \\
\hline Ratios in seawater & 0.022 & 0.227 & 0.044 & 1.160 & 0.121 \\
Ratios in precipitation & 0.124 & 0.298 & 0.844 & 1.384 & 0.847 \\
$\mathrm{EF}^{*}$ & 5.64 & 1.31 & 19.17 & 1.19 & 7.00 \\
\hline
\end{tabular}

* The enrichment factor for a given ionic species $\mathrm{X}$ is calculated using the following equation:

$\mathrm{EF}=\left[\mathrm{X} / \mathrm{Na}^{+}\right]_{\text {precipitation }} /\left[\mathrm{X} / \mathrm{Na}^{+}\right]_{\text {seawater. }}$.
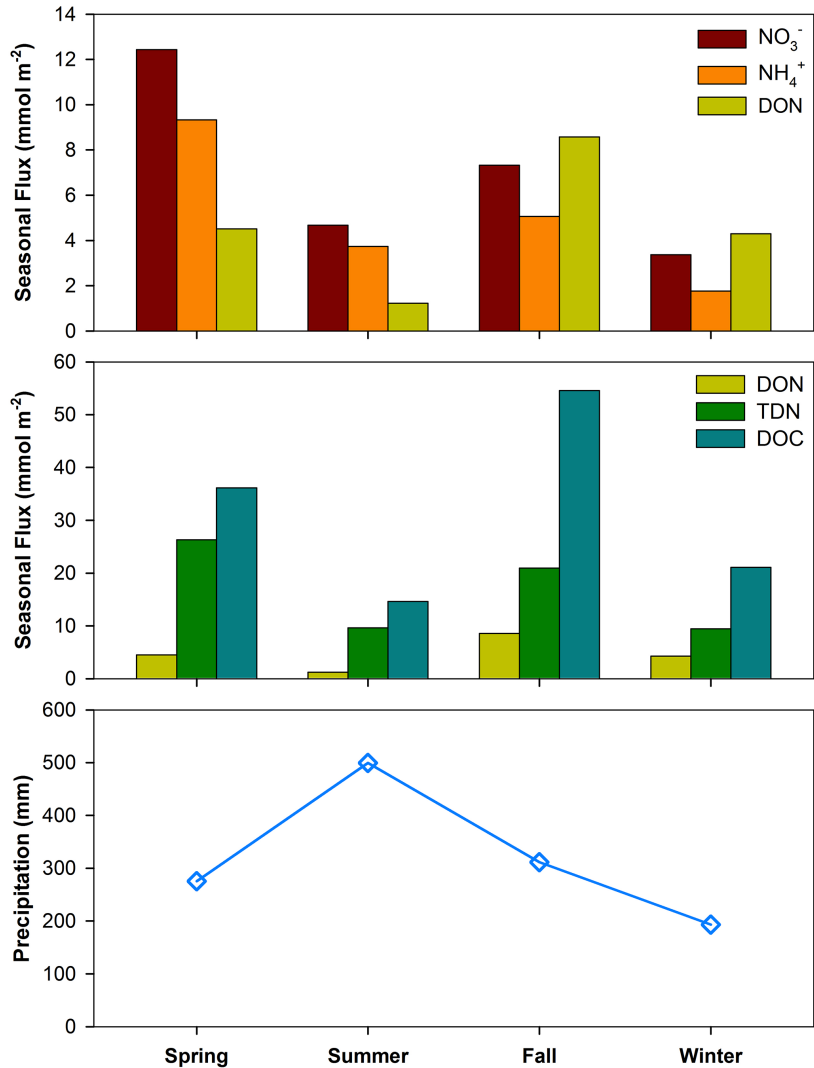

Figure 5. Seasonal wet depositional fluxes of $\mathrm{NO}_{3}^{-}, \mathrm{NH}_{4}^{+}, \mathrm{DON}$, TDN, and DOC at Uljin. The precipitation amounts for each season are also shown.

nitrogen fluxes. The seasonal variations in nitrogen fluxes are mainly attributed to the strength of emission sources located in Korea as well as other distant regions (see the discussion in Sect. 3.1.2).

In addition, the relative distributions of DON, TDN, and DOC fluxes were found to be in good agreement over all seasons (Fig. 5), implying there might exist an inherent link among these species. A statistically significant positive correlation $\left(R^{2}=0.64\right)$ was observed between the proportion of organic nitrogen $(\mathrm{ON})$ in total reactive nitrogen $(\mathrm{TN})$ and $\mathrm{ON}$ to organic carbon (OC) atomic ratio in dissolved organic matter in precipitation (Fig. 6). This study is the first to point out this correlation, but analysis of a larger data set consisting

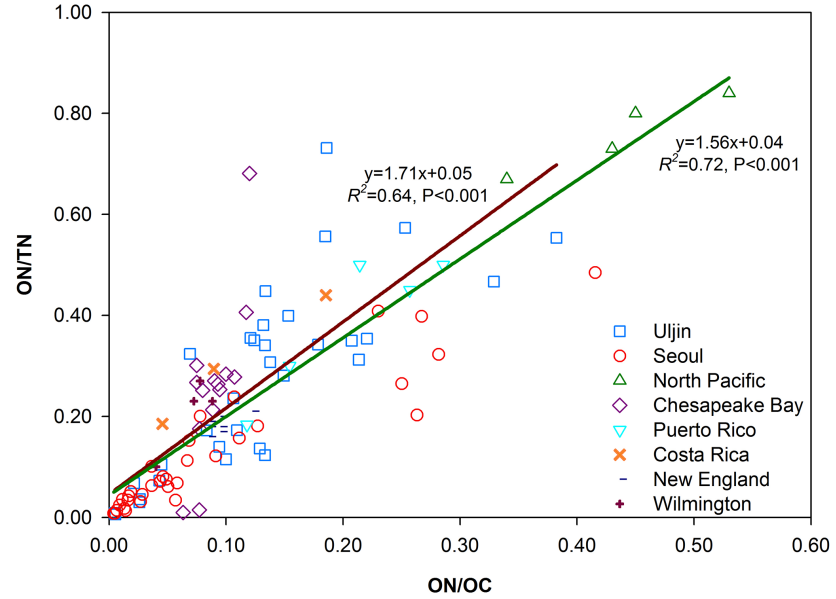

Figure 6. Plot of ON / TN versus ON / OC in precipitation samples collected at Uljin $(N=33)$ and Seoul $(N=33)$ in Korea and other locations worldwide, including the western North Pacific (aerosols, $N=4)$, Chesapeake Bay $(N=14)$, Puerto Rico $(N=5)$, Costa Rica $(N=3)$, New England $(N=15)$, and Wilmington $(N=4)$. The solid lines denote the best-fit correlations for Uljin data (red) and the entire data set (green).

of the available literature values and data obtained at our site and another location in Korea (Seoul) shows an even stronger correlation $\left(R^{2}=0.72\right)$ (Fig. 6). The correlation found in this data set is significant, since the data incorporate rainwater and aerosol samples collected worldwide from geographically varied locations (e.g., urban vs. rural, terrestrial vs. marine, and anthropogenic vs. pristine) (Jordan et al., 1995; Eklund and McDowell, 1997; Campbell et al., 2000; Kieber et al., 2005; Miyazaki et al., 2010; Gioda et al., 2011). Therefore, the trend observed herein is likely not simply coincidental, but universal.

Variations in the ON / OC ratio of airborne organic matter could reflect source variations, as being suggested by previous studies (Neff et al., 2002; Cape et al., 2011; Kanakidou et al., 2012). Specifically, the highest ON / OC ratios were observed for aerosols (total concentrations for aerosol sizes between 0.39 and $10.0 \mu \mathrm{m}$ ) over the remote North Pacific Ocean by Miyazaki et al. (2010), who also proposed that aerosols subject to increased biological influences were associated with higher ON / OC ratios. In contrast, the lowest $\mathrm{ON} / \mathrm{OC}$ ratios were mostly found for dissolved organic mat- 
Table 4. Annual atmospheric deposition fluxes of reactive nitrogen $\left(\mathrm{mmol} \mathrm{N} \mathrm{m}^{-2} \mathrm{yr}^{-1}\right)$ at coastal and marine locations estimated based on long-term measurements during the last decade.

\begin{tabular}{|c|c|c|c|c|c|c|c|c|}
\hline Location & Period & $\begin{array}{l}\text { Deposition } \\
\text { mode }\end{array}$ & $\mathrm{NO}_{3}^{-}$ & $\mathrm{NH}_{4}^{+}$ & DIN & DON & $\% \mathrm{DON}$ & Reference \\
\hline Uljin, Korea & 2011-2012 & wet & 28 & 20 & 48 & 19 & 28 & This study \\
\hline Donghae, Korea & 2002-2003 & dry & 27 & 6 & 33 & - & - & Kang et al. (2010) \\
\hline Taiwan & 2006 & dry & - & - & 39 & 22 & 36 & Chen et al. (2010) \\
\hline Shenzhen, China & 1986-2006 & wet & 37 & 58 & 95 & - & - & Huang et al. (2013) \\
\hline \multirow{2}{*}{ Singapore } & 2007-2008 & wet & 51 & 26 & 77 & 34 & 31 & He et al. (2011) \\
\hline & & dry & 19 & 3 & 21 & 21 & 50 & \\
\hline \multirow[t]{2}{*}{ Crete, Greece } & 2003-2006 & wet & 10 & 7 & 17 & 5 & 23 & Violaki et al. (2010) \\
\hline & & dry & 25 & 2 & 27 & 17 & 39 & \\
\hline Baltic Sea & 2001-2002 & wet plus dry & 21 & 19 & 40 & 4 & 9 & Rolff et al. (2008) \\
\hline Tampa Bay, USA & 2005 & wet & 23 & 10 & 33 & 2 & 6 & Calderon et al. (2007) \\
\hline \multirow[t]{2}{*}{ Barnegat Bay, USA } & 1999-2001 & wet & 29 & 19 & 48 & - & - & Gao (2002) \\
\hline & & dry & 4 & 2 & 6 & - & - & \\
\hline Miami, USA & 2007-2009 & wet & 15 & 12 & 27 & 2 & 7 & Zamora et al. (2011) \\
\hline Puerto Rico & 2004-2007 & wet & 6 & 4 & 10 & 7 & 41 & Gioda et al. (2011) \\
\hline
\end{tabular}

ter in precipitation samples collected in Seoul, where atmospheric organic matter is mainly derived from anthropogenic processes, especially fossil-fuel combustion (Yan and Kim, 2012). Atmospheric processing may also affect ON / OC ratios, as being seen in different types of aerosols that undergo various physical and photochemical atmospheric processes (Sun et al., 2011). In addition, it has been suggested that organic nitrogen tends to be less effectively removed from the atmosphere than inorganic nitrogen (Cornell, 2011 and references therein). Therefore, higher proportions of organic nitrogen might be linked to higher contributions from aged aerosols characterized by elevated ON / OC ratios (Sun et al., 2011).

The organic fraction of total reactive nitrogen in the atmosphere is highly variable in time and space, lacking a consistent trend on a global scale (Cornell, 2011; Jickells et al., 2013). In addition, the bioavailability of atmospheric organic nitrogen is poorly constrained (Duce et al., 2008; Kanakidou et al., 2012). Therefore, despite the fact that organic nitrogen is increasingly recognized as a significant factor in the atmospheric deposition of reactive nitrogen, its biogeochemical impact on receiving ecosystems (especially the ocean) remains unclear. The empirical relationship found in the present study between ON / TN and ON / OC (Fig. 6) suggests that the utilization potential (evaluated using ON / OC ratios) of atmospheric deposited organic nitrogen by marine biota is positively correlated with its proportion in total atmospheric reactive nitrogen. Thus, atmospheric deposition of organic nitrogen may play a vital role in supplying bioavailable nitrogen to the surface layer of marine systems, especially when inorganic nitrogen is less abundant, as is the case for the northwestern Pacific Ocean.

\subsubsection{Annual depositional fluxes of TDN at Uljin and over the EJS}

The annual wet depositional flux is calculated to be $28 \mathrm{mmol} \mathrm{N} \mathrm{m}^{-2} \mathrm{yr}^{-1}$ for $\mathrm{NO}_{3}^{-}, 20 \mathrm{mmol} \mathrm{N} \mathrm{m}^{-2} \mathrm{yr}^{-1}$ for $\mathrm{NH}_{4}^{+}$, and $19 \mathrm{mmol} \mathrm{N} \mathrm{m}^{-2} \mathrm{yr}^{-1}$ for DON (Table 4). Our estimates of inorganic nitrogen fluxes are higher than those obtained for dry deposition by Kang et al. (2010) at Donghae (Fig. 1), a coastal site adjacent to our sampling location. This is mainly due to the higher scavenging efficiency of airborne species by wet deposition comparing with dry deposition. In addition, the increasing anthropogenic emissions in East Asia may also contribute to this discrepancy (Galloway et al., 2004), as the sampling campaign by Kang et al. (2010) was conducted a decade ago. However, the fluxes of $\mathrm{NO}_{3}^{-}$for both deposition modes were similar, which can be attributed to the effective dry scavenging of $\mathrm{NO}_{3}^{-}$associated with coarse mode aerosols (Nakamura et al., 2005; Matsumoto et al., 2009). In general, atmospheric depositional fluxes of reactive nitrogen are higher in the coastal areas of East Asia (including the western coast of the EJS) than at other coastal locations around the world (Table 4). This is in agreement with the distribution of oceanic regions characterized by the most intensive atmospheric nitrogen deposition on a global basis (Dentener et al., 2006; Krishnamurthy et al., 2007). The considerable contributions by DON to atmospheric TDN fluxes (7-50\%) at these coastal/marine sites suggest the significant role of DON in supplying nitrogen to surface waters of the ocean.

Since our sampling site is located on the eastern coast of Korea, potential losses during transport must be considered when using the results of this study as a proxy for atmospheric depositional fluxes of reactive nitrogen over the remote EJS. Oki Island (Japan), an island located down- 
Table 5. Fractions of new primary production supported by atmospheric nitrogen input in world oceans on an annual basis.

\begin{tabular}{|c|c|c|c|c|c|}
\hline $\begin{array}{l}\text { Ocean } \\
\text { regions }\end{array}$ & $\begin{array}{l}\text { Deposition } \\
\text { mode }\end{array}$ & $\begin{array}{l}\text { Nitrogen } \\
\text { species }\end{array}$ & $\begin{array}{l}\text { Contribution to } \\
\text { new production }\end{array}$ & Method & Reference \\
\hline Southern East Sea/Sea of Japan & wet plus dry & TDN & $12-14 \%$ & field observation & This study \\
\hline Southern East Sea/Sea of Japan & wet plus dry & DIN & $\sim 10 \%$ & field observation & Kang et al. (2010) \\
\hline East Sea/Sea of Japan & wet plus dry & DIN & $2-12 \%$ & modeling & Onitsuka et al. (2009) \\
\hline Southern Yellow Sea & wet plus dry & DIN & $10.5 \%$ & field observation & Lv et al. (2005) \\
\hline Yellow Sea & wet plus dry & TDN & $0.3-6.7 \%$ & field observation & Qi et al. (2013) \\
\hline Southern East China Sea & dry & TDN & $8.3 \%$ & field observation & Chen et al. (2010) \\
\hline East China Sea & wet plus dry & DIN & $1.1-3.9 \%$ & modeling & Zhang et al. (2010) \\
\hline East China Sea & dry & DIN & $0.1-9 \%$ & field observation & Nakamura et al. (2005) \\
\hline South China Sea & wet plus dry & TDN & $20 \%$ & modeling & Kim et al. (2014a) \\
\hline Bay of Bengal & dry & TDN & up to $25 \%$ & field observation & Srinivas and Sarin (2013) \\
\hline Arabian Sea & dry & TDN & $<1 \%$ & field observation & Srinivas and Sarin (2013) \\
\hline Southeast Mediterranean Sea & wet plus dry & DIN & $8-20 \%$ & field observation & Herut et al. (1999) \\
\hline Western Mediterranean Sea & wet & DIN & $10-20 \%$ & field observation & Loye-Pilot et al. (1993) \\
\hline Eastern Atlantic & wet plus dry & DIN & $4-6 \%$ & field observation & Neuer et al. (2004) \\
\hline Bermuda & wet & TDN & $7-15 \%$ & field observation & Kim et al. (2014b) \\
\hline World oceans & wet plus dry & TDN & $1.5-6.9 \%$ & modeling & Duce et al. (2008) \\
\hline World oceans & wet plus dry & DIN & $5.1 \%$ & modeling & Krishnamurthy et al. (2010) \\
\hline
\end{tabular}

wind of Uljin in the eastern section of the southern EJS (Fig. 1), is mainly influenced by air masses originating from China and Korea, and shows a similar wet depositional flux of inorganic nitrogen to the values found in this study ( $45 \mathrm{mmol} \mathrm{N} \mathrm{m}^{-2} \mathrm{yr}^{-1}$; Japanese Acid Deposition Survey) (Kitayama et al., 2012). This implies that losses between the coast of Korea and offshore areas are small for wet depositional fluxes, as being shown for wet depositions of nitrogen over the eastern China Sea (Zhang et al., 2010). Therefore, our estimated atmospheric wet deposition flux can be extrapolated to the offshore region in the southern EJS. By taking the dry depositional flux of inorganic nitrogen observed at Oki Island $\left(35 \mathrm{mmol} \mathrm{N} \mathrm{m}^{-2} \mathrm{yr}^{-1}\right.$ for gases plus particles in 2003-2008) (Endo et al., 2011), the total (wet plus dry) inorganic nitrogen flux was calculated to be $83 \mathrm{mmolN} \mathrm{m}^{-2} \mathrm{yr}^{-1}$. Further, if assuming the same DON / TDN ratio in dry deposition as in wet deposition, the total atmospheric depositional flux of reactive nitrogen (organic plus inorganic) amounts to $115 \mathrm{mmol} \mathrm{N} \mathrm{m}^{-2} \mathrm{yr}^{-1}$ over the southern EJS.

\subsubsection{Biogeochemical implications}

Considering the prevailing westerly winds and the anthropogenic origins of these atmospheric reactive nitrogen species, their atmospheric deposition represents a source of new rather than recycled oceanic nitrogen to the EJS. Therefore, the atmospheric deposition of this nitrogen could presumably fuel the new primary production of this marine ecosystem. While inorganic nitrogen is readily utilized by marine biota, organic nitrogen is only partially available. The bioavailability of atmospheric organic nitrogen is largely determined by its chemical composition. Specifically, most re- duced organic nitrogen species (e.g., amino acids, urea, and amines) can be taken up by marine microorganisms on very short timescales, whereas the organic nitrogen associated with humic-like substances is probably refractory (Bronk et al., 2007). Incubation experiments estimate the bioavailability of atmospheric organic nitrogen to be $20-80 \%$ (Peierls and Paerl, 1997; Seitzinger and Sanders, 1999; Wedyan et al., 2007). Although not explicitly measured for the DON in our samples, a significant fraction is expected to be bioavailable, since it is mostly derived from agricultural activities that are known to produce large amounts of atmospheric reduced organic nitrogen, especially urea. Moreover, the severely $\mathrm{N}$ limited conditions of the EJS are likely to promote the utilization of atmospheric organic nitrogen. Assuming a bioavailability of $20-80 \%$ for DON and $100 \%$ for inorganic nitrogen, atmospheric deposition can supply approximately 89$109 \mathrm{mmol} \mathrm{m}^{-2} \mathrm{yr}^{-1}$ of reactive nitrogen to support primary production in the southern EJS.

Using a Redfield $\mathrm{C} / \mathrm{N}$ ratio of 6.625 , this nitrogen flux can be converted to $7.1-8.7 \mathrm{~g} \mathrm{C} \mathrm{m}^{-2} \mathrm{yr}^{-1}$ fixed by marine phytoplankton. This would account for $12-14 \%$ of new primary production in the southern EJS annually, which is taken to be $62 \mathrm{~g} \mathrm{C} \mathrm{m}^{-2} \mathrm{yr}^{-1}$ based on the particulate organic carbon export fluxes reported by Hahm and Kim (2001) (using tritium and helium isotopes) and Kim et al. (2011) (using ${ }^{234} \mathrm{Th} /{ }^{238} \mathrm{U}$ disequilibrium). Our estimate is higher than those obtained by Onitsuka et al. (2009) using a coupled physical-ecosystem model (6-12\% for the southern EJS from 1996 to 2003) and by Kang et al. (2010) based on field observations (ca. 10\%) (Table 5). These discrepancies can be ascribed to the inclusion of organic nitrogen in our study as well as a potential increase of nitrogen deposition resulting 
from growing anthropogenic emissions over the past decade. On a global scale, the value obtained for the southern EJS is generally at the higher level, comparing with other oceanic regions (Table 5). Taking into account that the southern EJS (especially the Ulleung Basin) is highly productive (Hyun et al., 2009), the estimate obtained in this study is rather remarkable. Such high estimates can be explained by the exceptionally high levels of atmospheric anthropogenic nitrogen deposition over the coastal seas downwind of East Asia (Krishnamurthy et al., 2007; Duce et al., 2008). Moreover, the contribution of atmospheric reactive nitrogen to biological productivity in the southern EJS is expected to be more pronounced during summer to fall, when the upward flux of nitrogen from the deep layer is suppressed by water column stratification (Kang et al., 2010; D. Kim et al., 2011).

The results presented here might be subject to large uncertainties, such as those associated with spatial variations of depositional fluxes across the EJS, the proportions of organic nitrogen in dry deposition, and the bioavailability of organic nitrogen in the atmosphere. Nevertheless, our estimation evidently suggests atmospheric transport represents a significant source of external nitrogen input to the southern EJS. Previous studies indicate that $\mathrm{N}_{2}$ fixation is insignificant to the nitrogen budget of this marine system (Yanagi, 2002; Kang et al., 2010). Therefore, in addition to nitrogen upwelled from below the euphotic zone and transported by the Tsushima Warm Current through the Korea/Tsushima Strait (Onitsuka et al., 2007; Yoo and Park, 2009), atmospheric deposition could sustain a considerable fraction of the nitrogen demand by primary productivity in the southern EJS, especially the offshore region. Moreover, the elevated nitrogen deposition may modify the nutrient limitation regime (Duce et al., 2008) of the EJS and thus impact the phytoplankton community structure therein (Krishnamurthy et al., 2007; Galloway et al., 2008). Due to climate warming, El Niño is likely to become more prevalent in the future, which could result in suppression of the nutricline and thus restriction of nutrient upwelling from deep waters (Mackey et al., 2010). Conversely, the anthropogenic nitrogen deposition over the northwestern Pacific Ocean is predicted to increase in the near future (Duce et al., 2008). Consequently, atmospheric deposition of nitrogen is expected to play an increasingly important role in the biogeochemistry of the northwestern Pacific Ocean and the EJS over the coming decades. Special attentions should be given to the organic fraction, since little is known with respect to its sources and distributions, rendering the regulation of emission as well as the prediction on its future trend rather difficult.

\section{Conclusions}

Dissolved reactive nitrogen species were investigated in precipitation samples collected over a 1-year period (20112012) at Uljin, a coastal site upwind of the southern EJS. Inorganic nitrogen was found to be mostly derived from the Asian continent (particularly eastern and northeastern China) through long-range atmospheric transport, whereas the primary sources of DON are distributed within Korea. Furthermore, agricultural activities (e.g., animal husbandry and the application of synthetic fertilizer) were identified as the major emission source for DON. A positive correlation was found between the proportion of organic nitrogen in total reactive nitrogen and nitrogen to carbon ratio in organic matter, implying that the biogeochemical impact of organic nitrogen deposition is especially significant (i.e., more bioavailable) when inorganic nitrogen is less abundant. By combining the wet depositional flux recorded at Uljin with the dry depositional flux reported for Oki Island, the total (wet plus dry) atmospheric deposition of reactive inorganic and organic nitrogen to the southern EJS was estimated to be $115 \mathrm{mmol} \mathrm{N} \mathrm{m} \mathrm{yr}^{-1}$. This flux could potentially support $12-14 \%$ of the new primary production of the southern EJS on an annual basis, of which up to $3.4 \%$ would be attributed to organic nitrogen. The results presented in this paper emphasize the significant impact of atmospheric nitrogen deposition on the biogeochemistry of the EJS and by extension the northwestern Pacific Ocean. The development of this impact in response to climate change and growing anthropogenic emissions should be routinely monitored, especially in the case of organic nitrogen. More extensive information might be required to better understand the biogeochemical role of atmospheric nitrogen deposition, such as microorganisms community structure, the availability of other limiting nutrients (e.g., Fe and P), and the quantity and bioavailability of the insoluble fraction of organic nitrogen.

Acknowledgements. This research was supported by the Korea Meteorological Administration Research and Development Program under grant CATER 2012-7170 and the National Research Foundation of Korea (NRF) grant funded by the Korea government (MSIP) (NRF-2013R1A2A1A05004343). Ge Yan was partially supported by the BK21 scholarship through School of Earth and Environmental Sciences, Seoul National University, Korea. We are grateful to Yonghwa Oh and Jeonghyun Kim for their assistance with sample collection. We also acknowledge the NOAA Air Resources Laboratory for provision of HYSPLIT transport model.

Edited by: N. Mihalopoulos 


\section{References}

Beddig, S., Brockmann, U., Dannecker, W., Korner, D., Pohlmann, T., Puls, W., Radach, G., Rebers, A., Rick, H. J., Schatzmann, M., Schlunzen, H., and Schulz, M.: Nitrogen fluxes in the German Bight, Mar. Pollut. Bull., 34, 382-394, 1997.

Bronk, D. A., See, J. H., Bradley, P., and Killberg, L.: DON as a source of bioavailable nitrogen for phytoplankton, Biogeosciences, 4, 283-296, doi:10.5194/bg-4-283-2007, 2007.

Calderon, S. M., Poor, N. D., and Campbell, S. W.: Estimation of the particle and gas scavenging contributions to wet deposition of organic nitrogen, Atmos. Environ., 41, 4281-4290, 2007.

Campbell, J. L., Hornbeck, J. W., McDowell, W. H., Buso, D. C., Shanley, J. B., and Likens, G. E.: Dissolved organic nitrogen budgets for upland, forested ecosystems in New England, Biogeochemistry, 49, 123-142, 2000.

Cape, J. N., Cornell, S. E., Jickells, T. D., and Nemitz, E.: Organic nitrogen in the atmosphere - Where does it come from? A review of sources and methods, Atmos. Res., 102, 30-48, 2011.

Castro, M. S. and Driscoll, C. T.: Atmospheric nitrogen deposition to estuaries in the mid-Atlantic and northeastern United States, Environ. Sci. Technol., 36, 3242-3249, 2002.

Chen, H. Y., Chen, L. D., Chiang, Z. Y., Hung, C. C., Lin, F. J., Chou, W. C., Gong, G. C., and Wen, L. S.: Size fractionation and molecular composition of water-soluble inorganic and organic nitrogen in aerosols of a coastal environment, J. Geophys. Res.Atmos., 115, D22307, doi:10.1029/2010JD014157, 2010.

Chen, N. W., Hong, H. S., Huang, Q. J., and Wu, J. Z.: Atmospheric nitrogen deposition and its long-term dynamics in a southeast China coastal area, J. Environ. Manage., 92, 1663-1667, 2011.

Cooke, W. F., Liousse, C., Cachier, H., and Feichter, J.: Construction of a $1^{\circ} \times 1^{\circ}$ fossil fuel emission data set for carbonaceous aerosol and implementation and radiative impact in the ECHAM4 model, J. Geophys. Res.-Atmos., 104, 22137-22162, doi:10.1029/1999JD900187, 1999.

Cornell, S. E.: Atmospheric nitrogen deposition: Revisiting the question of the importance of the organic component, Environ. Pollut., 159, 2214-2222, 2011.

Cornell, S. E., Jickells, T. D., and Thornton, C. A.: Urea in rainwater and atmospheric aerosol, Atmos. Environ., 32, 1903-1910, 1998.

Cornell, S. E., Jickells, T. D., Cape, J. N., Rowland, A. P., and Duce, R.A.: Organic nitrogen deposition on land and coastal environments: a review of methods and data, Atmos. Environ., 37, 21732191, 2003.

de Leeuw, G., Spokes, L., Jickells, T., Skjoth, C. A., Hertel, O., Vignati, E., Tamm, S., Schulz, M., Sorensen, L. L., Pedersen, B., Klein, L., and Schlunzen, K. H.: Atmospheric nitrogen inputs into the North Sea: effect on productivity, Cont. Shelf Res., 23, 1743-1755, 2003.

Dentener, F., Drevet, J., Lamarque, J. F., Bey, I., Eickhout, B., Fiore, A. M., Hauglustaine, D., Horowitz, L. W., Krol, M., Kulshrestha, U. C., Lawrence, M., Galy-Lacaux, C., Rast, S., Shindell, D., Stevenson, D., Van Noije, T., Atherton, C., Bell, N., Bergman, D., Butler, T., Cofala, J., Collins, B., Doherty, R., Ellingsen, K., Galloway, J., Gauss, M., Montanaro, V., Muller, J. F., Pitari, G., Rodriguez, J., Sanderson, M., Solmon, F., Strahan, S., Schultz, M., Sudo, K., Szopa, S., and Wild, O.: Nitrogen and sulfur deposition on regional and global scales: A multimodel evaluation, Global Biogeochem. Cy., 20, GB4003, doi:10.1029/2005GB002672, 2006.
Doney, S. C., Mahowald, N., Lima, I., Feely, R. A., Mackenzie, F. T., Lamarque, J. F., and Rasch, P. J.: Impact of anthropogenic atmospheric nitrogen and sulfur deposition on ocean acidification and the inorganic carbon system, P. Natl. Acad. Sci. USA, 104, 14580-14585, 2007.

Draxler, R. R. and Hess, G. D.: An overview of the HYSPLIT_4 modelling system for trajectories, dispersion and deposition, Aust. Meteorol. Mag., 47, 295-308, 1998.

Duce, R. A., LaRoche, J., Altieri, K., Arrigo, K. R., Baker, A. R., Capone, D. G., Cornell, S., Dentener, F., Galloway, J., Ganeshram, R. S., Geider, R. J., Jickells, T., Kuypers, M. M., Langlois, R., Liss, P. S., Liu, S. M., Middelburg, J. J., Moore, C. M., Nickovic, S., Oschlies, A., Pedersen, T., Prospero, J., Schlitzer, R., Seitzinger, S., Sorensen, L. L., Uematsu, M., Ulloa, O., Voss, M., Ward, B., and Zamora, L.: Impacts of atmospheric anthropogenic nitrogen on the open ocean, Science, 320 , 893-897, 2008.

Eklund, T. J., Mcdowell, W. H., and Pringle, C. M.: Seasonal variation of tropical precipitation chemistry: La Selva, Costa Rica, Atmos. Environ., 31, 3903-3910, 1997.

Endo, T., Yagoh, H., Sato, K., Matsuda, K., Hayashi, K., Noguchi, I., and Sawada, K.: Regional characteristics of dry deposition of sulfur and nitrogen compounds at EANET sites in Japan from 2003 to 2008, Atmos. Environ., 45, 1259-1267, 2011.

Fahey, T. J., Williams, C. J., Rooney-Varga, J. N., Cleveland, C. C., Postek, K. M., Smith, S. D., and Bouldin, D. R.: Nitrogen deposition in and around an intensive agricultural district in central New York, J. Environ. Qual., 28, 1585-1600, 1999.

Fowler, D., Coyle, M., Skiba, U., Sutton, M. A., Cape, J. N., Reis, S., Sheppard, L. J., Jenkins, A., Grizzetti, B., Galloway, J. N., Vitousek, P., Leach, A., Bouwman, A. F., Butterbach-Bahl, K., Dentener, F., Stevenson, D., Amann, M., and Voss, M.: The global nitrogen cycle in the twenty-first century, Phil. Trans. R. Soc. B, 368, 20130164, doi:10.1098/rstb.2013.0164, 2013.

Gabriel, R., Mayol-Bracero, O. L., and Andreae, M. O.: Chemical characterization of submicron aerosol particles collected over the Indian Ocean, J. Geophys. Res.-Atmos., 107, 8005, doi:10.1029/2000JD000034, 2002.

Galloway, J. N., Dentener, F. J., Capone, D. G., Boyer, E. W., Howarth, R. W., Seitzinger, S. P., Asner, G. P., Cleveland, C. C., Green, P. A., Holland, E. A., Karl, D. M., Michaels, A. F., Porter, J. H., Townsend, A. R., and Vorosmarty, C. J.: Nitrogen cycles: past, present, and future, Biogeochemistry, 70, 153-226, 2004.

Galloway, J. N., Townsend, A. R., Erisman, J. W., Bekunda, M., Cai, Z. C., Freney, J. R., Martinelli, L. A., Seitzinger, S. P., and Sutton, M. A.: Transformation of the nitrogen cycle: Recent trends, questions, and potential solutions, Science, 320, 889-892, 2008.

Gao, Y. A.: Atmospheric nitrogen deposition to Barnegat Bay, Atmos. Environ., 36, 5783-5794, 2002.

Gioda, A., Reyes-Rodriguez, G. J., Santos-Figueroa, G., Collett, J. L., Decesari, S., Ramos, M. D. K. V., Netto, H. J. C. B., Neto, F. R. D., and Mayol-Bracero, O. L.: Speciation of water-soluble inorganic, organic, and total nitrogen in a background marine environment: Cloud water, rainwater, and aerosol particles, J. Geophys. Res.-Atmos., 116, D05203, doi:10.1029/2010JD015010, 2011.

Gruber, N. and Galloway, J. N.: An Earth-system perspective of the global nitrogen cycle, Nature, 451, 293-296, 2008. 
Hahm, D. and Kim, K.-R.: An estimation of the new production in the southern East Sea using helium isotopes, J. Korean Soc. Oceanogr., 36, 19-26, 2001.

He, J., Balasubramanian, R., Burger, D. F., Hicks, K., Kuylenstierna, J. C. I., and Palani, S.: Dry and wet atmospheric deposition of nitrogen and phosphorus in Singapore, Atmos. Environ., 45, 2760-2768, 2011.

Herut, B., Krom, M. D., Pan, G., and Mortimer, R.: Atmospheric input of nitrogen and phosphorus to the Southeast Mediterranean: Sources, fluxes, and possible impact, Limnol. Oceanogr., 44, 1683-1692, 1999.

Hu, G. P., Balasubramanian, R., and Wu, C. D.: Chemical characterization of rainwater at Singapore, Chemosphere, 51, 747-755, 2003.

Huang, Y. L., Lu, X. X., and Chen, K.: Wet atmospheric deposition of nitrogen: 20 years measurement in Shenzhen City, China, Environ. Monit. Assess., 185, 113-122, 2013.

Hyun, J. H., Kim, D., Shin, C. W., Noh, J. H., Yang, E. J., Mok, J. S., Kim, S. H., Kim, H. C., and Yoo, S.: Enhanced phytoplankton and bacterioplankton production coupled to coastal upwelling and an anticyclonic eddy in the Ulleung Basin, East Sea, Aquat. Microb. Ecol., 54, 45-54, 2009.

International Fertilizer Industry Association (IFA), Statistics Databases: available at: http://www.fertilizer.org/, last access: 1 August 2014.

Ito, A., Lin, G., and Penner, J. E.: Reconciling modeled and observed atmospheric deposition of soluble organic nitrogen at coastal locations, Global Biogeochem. Cy., 28, 617-630, doi:10.1002/2013GB004721, 2014.

Jenkins, W. J.: The biogeochemical consequences of changing ventilation in the Japan/East Sea, Mar. Chem., 108, 137-147, 2008. Jeong, J. I. and Park, S. U.: Interaction of gaseous pollutants with aerosols in Asia during March 2002, Sci. Total Environ., 392, 262-276, 2008.

Jickells, T.: The role of air-sea exchange in the marine nitrogen cycle, Biogeosciences, 3, 271-280, doi:10.5194/bg-3-271-2006, 2006.

Jickells, T., Baker, A. R., Cape, J. N., Cornell, S. E., and Nemitz, E.: The cycling of organic nitrogen through the atmosphere, Phil. Trans. R. Soc. B, 368, 20130115, doi:10.1098/rstb.2013.0115, 2013.

Jo, C. O., Lee, J. Y., Park, K. A., Kim, Y. H., and Kim, K. R.: Asian dust initiated early spring bloom in the northern East/Japan Sea, Geophys. Res. Lett., 34, L05602, doi:10.1029/2006GL027395, 2007.

Jordan, T. E., Correll, D. L., Weller, D. E., and Goff, N. M.: Temporal Variation in Precipitation Chemistry on the Shore of the Chesapeake Bay, Water Air Soil Poll., 83, 263-284, 1995.

Kanakidou, M., Duce, R. A., Prospero, J. M., Baker, A. R., BenitezNelson, C., Dentener, F. J., Hunter, K. A., Liss, P. S., Mahowald, N., Okin, G. S., Sarin, M., Tsigaridis, K., Uematsu, M., Zamora, L. M., and Zhu, T.: Atmospheric fluxes of organic N and $\mathrm{P}$ to the global ocean, Global Biogeochem. Cy., 26, GB3026, doi:10.1029/2011GB004277, 2012.

Kang, J., Choi, M. S., and Lee, C. B.: Atmospheric metal and phosphorus concentrations, inputs, and their biogeochemical significances in the Japan/East Sea, Sci. Total Environ., 407, 22702284, 2009.
Kang, J., Cho, B. C., and Lee, C. B.: Atmospheric transport of water-soluble ions $\left(\mathrm{NO}_{3}^{-}, \mathrm{NH}_{4}^{+}\right.$and nss- $\left.\mathrm{SO}_{4}^{2-}\right)$ to the southern East Sea (Sea of Japan), Sci. Total. Environ., 408, 2369-2377, 2010.

Kang, J., Choi, M. S., Yi, H. I., Song, Y. H., Lee, D., and Cho, J. H.: A five-year observation of atmospheric metals on Ulleung Island in the East/Japan Sea: Temporal variability and source identification, Atmos. Environ., 45, 4252-4262, 2011.

Keene, W. C., Pszenny, A. A. P., Galloway, J. N., and Hawley, M. E.: Sea-Salt Corrections and Interpretation of Constituent Ratios in Marine Precipitation, J. Geophys. Res.-Atmos., 91, 6647-6658, doi:10.1029/JD091ID06P06647, 1986.

Keene, W. C., Montag, J. A., Maben, J. R., Southwell, M., Leonard, J., Church, T. M., Moody, J. L., and Galloway, J. N.: Organic nitrogen in precipitation over Eastern North America, Atmos. Environ., 36, 4529-4540, 2002.

Kieber, R. J., Long, M. S., and Willey, J. D.: Factors influencing nitrogen speciation in coastal rainwater, J. Atmos. Chem., 52, 81-99, 2005.

Kim, D., Choi, M. S., Oh, H. Y., Song, Y. H., Noh, J. H., and Kim, K. H.: Seasonal export fluxes of particulate organic carbon from Th234/U-238 disequilibrium measurements in the Ulleung Basin (Tsushima Basin) of the East Sea (Sea of Japan), J. Oceanogr., 67, 577-588, 2011.

Kim, J.: Transport routes and source regions of Asian dust observed in Korea during the past 40 years (1965-2004), Atmos. Environ., 42, 4778-4789, 2008.

Kim, J., Yoon, S. C., Jefferson, A., Zahorowski, W., and Kang, C. H.: Air mass characterization and source region analysis for the Gosan super-site, Korea, during the ACE-Asia 2001 field campaign, Atmos. Environ., 39, 6513-6523, 2005.

Kim, S. K., Chang, K. I., Kim, B., and Cho, Y. K.: Contribution of ocean current to the increase in $\mathrm{N}$ abundance in the Northwestern Pacific marginal seas, Geophys. Res. Lett., 40, 143-148, doi:10.1029/2012GL054545, 2013.

Kim, T. H. and Kim, G.: Changes in seawater $\mathrm{N}: \mathrm{P}$ ratios in the northwestern Pacific Ocean in response to increasing atmospheric N deposition: Results from the East (Japan) Sea, Limnol. Oceanogr., 58, 1907-1914, 2013.

Kim, T. W., Lee, K., Najjar, R. G., Jeong, H. D., and Jeong, H. J.: Increasing N Abundance in the Northwestern Pacific Ocean Due to Atmospheric Nitrogen Deposition, Science, 334, 505-509, 2011.

Kim, T. W., Lee, K., Duce, R., and Liss, P.: Impact of atmospheric nitrogen deposition on phytoplankton productivity in the South China Sea, Geophys. Res. Lett., 41, 3156-3162, doi:10.1002/2014GL059665, 2014a.

Kim, T. W., Najjar, R. G., and Lee, K.: Influence of precipitation events on phytoplankton biomass in coastal waters of the eastern United States, Global Biogeochem. Cy., 28, 1-13, doi:10.1002/2013GB004712, 2014b.

Kitayama, K., Seto, S., Sato, M., and Hara, H.: Increases of wet deposition at remote sites in Japan from 1991 to 2009, J. Atmos. Chem., 69, 33-46, 2012.

Krishnamurthy, A., Moore, J. K., Zender, C. S., and Luo, C.: Effects of atmospheric inorganic nitrogen deposition on ocean biogeochemistry, J. Geophys. Res.-Biogeo., 112, G02019, doi:10.1029/2006JG000334, 2007.

Krishnamurthy, A., Moore, J. K., Mahowald, N., Luo, C., and Zender, C. S.: Impacts of atmospheric nutrient inputs on ma- 
rine biogeochemistry, J. Geophys. Res.-Biogeo., 115, G01006, doi:10.1029/2009JG001115, 2010.

Lee, H. J., Kim, S. W., Brioude, J., Cooper, O. R., Frost, G. J., Kim, C. H., Park, R. J., Trainer, M., and Woo, J. H.: Transport of NOx in East Asia identified by satellite and in situ measurements and Lagrangian particle dispersion model simulations, J. Geophys. Res.-Atmos., 119, 2574-2596, doi:10.1002/2013JD021185, 2014.

Lee, K. S., Lee, D. S., Lim, S. S., Kwak, J. H., Jeon, B. J., Lee, S. I., Lee, S. M., and Choi, W. J.: Nitrogen isotope ratios of dissolved organic nitrogen in wet precipitation in a metropolis surrounded by agricultural areas in southern Korea, Agr. Ecosyst. Environ., 159, 161-169, 2012.

Lesworth, T., Baker, A. R., and Jickells, T.: Aerosol organic nitrogen over the remote Atlantic Ocean, Atmos. Environ., 44, 18871893, 2010.

Loye-Pilot, M. D., Klein, C., and Martin, J. M.: Major inorganic elements in north western Mediterranean aerosols: Concentrations and sources, Estimation of dry deposition of soluble inorganic nitrogen, in: Water Pollution Reports, Rep. 20, edited by: Martin, J. M. and Barth, H., Eur. Union, Brussels, 271-277, 1993.

Luo, Y. Z., Yang, X. S., Carley, R. J., and Perkins, C.: Atmospheric deposition of nitrogen along the Connecticut coastline of Long Island Sound: a decade of measurements, Atmos. Environ., 36, 4517-4528, 2002.

Lv, X., Song, J., Yuan, H., Li, X., Zhan, T., Li, N., and Gao, X.: Distribution characteristics of nitrogen in the southern Yellow sea surface sediments and nitrogen functions in biogeochemical cycling, Geol. Rev., 51, 212-218, 2005.

Mace, K. A., Duce, R. A., and Tindale, N. W.: Organic nitrogen in rain and aerosol at Cape Grim, Tasmania, Australia, J. Geophys. Res.-Atmos., 108, 4338, doi:10.1029/2002JD003051, $2003 \mathrm{a}$.

Mace, K. A., Kubilay, N., and Duce, R. A.: Organic nitrogen in rain and aerosol in the eastern Mediterranean atmosphere: An association with atmospheric dust, J. Geophys. Res.-Atmos., 108, 4320, doi:10.1029/2002JD002997, 2003 b.

Mackey, K. R. M., van Dijken, G. L., Mazloom, S., Erhardt, A. M., Ryan, J., Arrigo, K. R., and Paytan, A.: Influence of atmospheric nutrients on primary productivity in a coastal upwelling region, Global Biogeochem. Cy., 24, GB4027, doi:10.1029/2009GB003737, 2010.

Matsumoto, K., Minami, H., Uyama, Y., and Uematsu, M.: Size partitioning of particulate inorganic nitrogen species between the fine and coarse mode ranges and its implication to their deposition on the surface ocean, Atmos. Environ., 43, 4259-4265, 2009.

Miyazaki, Y., Kawamura, K., and Sawano, M.: Size distributions of organic nitrogen and carbon in remote marine aerosols: Evidence of marine biological origin based on their isotopic ratios, Geophys. Res. Lett., 37, L06803, doi:10.1029/2010GL042483, 2010.

Nakamura, T., Matsumoto, K., and Uematsu, M.: Chemical characteristics of aerosols transported from Asia to the East China Sea: an evaluation of anthropogenic combined nitrogen deposition in autumn, Atmos. Environ., 39, 1749-1758, 2005.

Neff, J. C., Holland, E. A., Dentener, F. J., McDowell, W. H., and Russell, K. M.: The origin, composition and rates of organic nitrogen deposition: A missing piece of the nitrogen cycle?, Biogeochemistry, 57, 99-136, 2002.
Neuer, S., Torres-Padron, M. E., Gelado-Caballero, M. D., Rueda, M. J., Hernandez-Brito, J., Davenport, R., and Wefer, G.: Dust deposition pulses to the eastern subtropical North Atlantic gyre: Does ocean's biogeochemistry respond?, Global Biogeochem. Cy., 18, GB4020, doi:10.1029/2004GB002228, 2004.

Onitsuka, G., Yanagi, T., and Yoon, J. H.: A numerical study on nutrient sources in the surface layer of the Japan Sea using a coupled physical-ecosystem model, J. Geophys. Res.-Oceans, 112, C05042, doi:10.1029/2006JC003981, 2007.

Onitsuka, G., Uno, I., Yanagi, T., and Yoon, J. H.: Modeling the effects of atmospheric nitrogen input on biological production in the Japan Sea, J. Oceanogr., 65, 433-438, 2009.

Paytan, A., Shellenbarger, G. G., Street, J. H., Gonneea, M. E., Davis, K., Young, M. B., and Moore, W. S.: Submarine groundwater discharge: An important source of new inorganic nitrogen to coral reef ecosystems, Limnol. Oceanogr., 51, 343-348, 2006.

Peierls, B. L. and Paerl, H. W.: Bioavailability of atmospheric organic nitrogen deposition to coastal phytoplankton, Limnol. Oceanogr., 42, 1819-1823, 1997.

Poissant, L., Schmit, J. P., and Beron, P.: Trace Inorganic Elements in Rainfall in the Montreal Island, Atmos. Environ., 28, 339-346, 1994.

Qi, J. H., Shi, J. H., Gao, H. W., and Sun, Z.: Atmospheric dry and wet deposition of nitrogen species and its implication for primary productivity in coastal region of the Yellow Sea, China, Atmos. Environ., 81, 600-608, 2013.

Richter, A., Burrows, J. P., Nuss, H., Granier, C., and Niemeier, U.: Increase in tropospheric nitrogen dioxide over China observed from space, Nature, 437, 129-132, 2005.

Rolff, C., Elmgren, R., and Voss, M.: Deposition of nitrogen and phosphorus on the Baltic Sea: seasonal patterns and nitrogen isotope composition, Biogeosciences, 5, 1657-1667, doi:10.5194/bg-5-1657-2008, 2008.

Seitzinger, S. P. and Sanders, R. W.: Atmospheric inputs of dissolved organic nitrogen stimulate estuarine bacteria and phytoplankton, Limnol. Oceanogr., 44, 721-730, 1999.

Seitzinger, S. P., Harrison, J. A., Dumont, E., Beusen, A. H. W., and Bouwman, A. F.: Sources and delivery of carbon, nitrogen, and phosphorus to the coastal zone: An overview of Global Nutrient Export from Watersheds (NEWS) models and their application, Global Biogeochem. Cy., 19, GB4S01, doi:10.1029/2005GB002606, 2005.

Song, F. and Gao, Y.: Chemical characteristics of precipitation at metropolitan Newark in the US East Coast, Atmos. Environ., 43, 4903-4913, 2009.

Spokes, L. J. and Jickells, T. D.: Is the atmosphere really an important source of reactive nitrogen to coastal waters?, Cont. Shelf Res., 25, 2022-2035, 2005.

Srinivas, B. and Sarin, M. M.: Atmospheric deposition of N, P and $\mathrm{Fe}$ to the Northern Indian Ocean: Implications to $\mathrm{C}$ - and $\mathrm{N}$ fixation, Sci. Total Environ., 456, 104-114, 2013.

Sun, Y.-L., Zhang, Q., Schwab, J. J., Demerjian, K. L., Chen, W.N., Bae, M.-S., Hung, H.-M., Hogrefe, O., Frank, B., Rattigan, O. V., and Lin, Y.-C.: Characterization of the sources and processes of organic and inorganic aerosols in New York city with a high-resolution time-of-flight aerosol mass apectrometer, Atmos. Chem. Phys., 11, 1581-1602, doi:10.5194/acp-11-15812011, 2011. 
Talley, L. D., Tishchenko, P., Luchin, V., Nedashkovskiy, A., Sagalaev, S., Kang, D. J., Warner, M., and Min, D. H.: Atlas of Japan (East) Sea hydrographic properties in summer, 1999, Prog. Oceanogr., 61, 277-348, 2004.

Topol, L., Levon, M., Flanagan, J., Schwall, R., and Jackson, A.: Quality Assurance Management for Precipitation Systems, EPA/600/4-82-042a, Environmental Protection Agency, Research Triangle Park, North Carolina, 1985.

Uno, I., Uematsu, M., Hara, Y., He, Y. J., Ohara, T., Mori, A., Kamaya, T., Murano, K., Sadanaga, Y., and Bandow, H.: Numerical study of the atmospheric input of anthropogenic total nitrate to the marginal seas in the western North Pacific region, Geophys. Res. Lett., 34, L17817, doi:10.1029/2007GL030338, 2007.

Violaki, K., Zarbas, P., and Mihalopoulos, N.: Long-term measurements of dissolved organic nitrogen (DON) in atmospheric deposition in the Eastern Mediterranean: Fluxes, origin and biogeochemical implications, Mar. Chem., 120, 179-186, 2010.

Vitousek, P. M. and Howarth, R. W.: Nitrogen Limitation on Land and in the Sea - How Can It Occur?, Biogeochemistry, 13, 87$115,1991$.

Wai, K. M., Lin, N. H., Wang, S. H., and Dokiya, Y.: Rainwater chemistry at a high-altitude station, Mt. Lulin, Taiwan: comparison with a background station, Mt. Fuji, J. Geophys. Res.Atmos., 113, D06305, doi:10.1029/2006JD008248, 2008.

Walker, J. T., Dombek, T. L., Green, L. A., Gartman, N., and Lehmann, C. M. B.: Stability of organic nitrogen in NADP wet deposition samples, Atmo. Environ., 60, 573-582, 2012.

Wedyan, M. A., Fandi, K. G., and Al-Rousan, S.: Bioavailability of atmospheric dissolved organic nitrogen in the marine aerosols over the Gulf of Aqaba, Austr. J. Basic Appl. Sci., 1, 208-212, 2007.

Yan, G. and Kim, G.: Dissolved organic carbon in the precipitation of Seoul, Korea: Implications for global wet depositional flux of fossil-fuel derived organic carbon, Atmos. Environ., 59, 117$124,2012$.
Yanagi, T.: Water, salt, phosphorus and nitrogen budgets of the Japan Sea, J. Oceanogr., 58, 797-804, 2002.

Yoo, S. and Park, J.: Why is the southwest the most productive region of the East Sea/Sea of Japan?, J. Marine Syst., 78, 301-315, 2009.

Zamora, L. M., Prospero, J. M., and Hansell, D. A.: Organic nitrogen in aerosols and precipitation at Barbados and Miami: Implications regarding sources, transport and deposition to the western subtropical North Atlantic, J. Geophys. Res.-Atmos., 116, D20309, doi:10.1029/2011JD015660, 2011.

Zhang, J., Zhang, G. S., Bi, Y. F., and Liu, S. M.: Nitrogen species in rainwater and aerosols of the Yellow and East China seas: Effects of the East Asian monsoon and anthropogenic emissions and relevance for the NW Pacific Ocean, Global Biogeochem. Cy., 25, GB3020, doi:10.1029/2010GB003896, 2011.

Zhang, Q. and Anastasio, C.: Chemistry of fog waters in California's Central Valley - Part 3: concentrations and speciation of organic and inorganic nitrogen, Atmos. Environ., 35, 5629-5643, 2001.

Zhang, Y., Zheng, L. X., Liu, X. J., Jickells, T., Cape, J. N., Goulding, K., Fangmeier, A., and Zhang, F. S.: Evidence for organic N deposition and its anthropogenic sources in China, Atmos. Environ., 42, 1035-1041, 2008.

Zhang, Y., Yu, Q., Ma, W. C., and Chen, L. M.: Atmospheric deposition of inorganic nitrogen to the eastern China seas and its implications to marine biogeochemistry, J. Geophys. Res.-Atmos., 115, D00K10, doi:10.1029/2009JD012814, 2010.

Zhang, Y., Song, L., Liu, X. J., Li, W. Q., Lu, S. H., Zheng, L. X., Bai, Z. C., Cai, G. Y., and Zhang, F. S.: Atmospheric organic nitrogen deposition in China, Atmos. Environ., 46, 195-204, 2012. 